\title{
Work and Learning Conference, University of Chester, 29 May 2020
}

\section{Universities Association for Lifelong Learning (UALL) Work and Learning Conference, University of Chester, 29 May 2020}

The Universities Association for Lifelong Learning (UALL) [1] is the longest established charitable organisation in the UK dedicated to furthering the cause of lifelong learning in higher education. It was created in the wake of what is referred to as the "1919 Report", which led to the establishment of adult learning centres in British universities (HM Government, 1919).

To quote its own mission statement "The Association seeks to champion the broader definition of lifelong engagement with universities through part-time flexible provision offering personal, community and vocational development. It does so through advocacy in policy development, dissemination of information on policy, practice and funding through a lively programme of events, and through research and publication."

As part of its work UALL sponsors a number of specialist networks, including the Work and Learning Network. The Network has a website where it is planned will contain a number of resources for practitioners in the field [2]. Membership of the Network is free and extends beyond the UALL membership to engage with a wide range of practitioners engaged in workbased learning (WBL). WBL in this sense includes all stakeholders associated with programmes where students are studying full time but seeking entry to the labour market, through mechanisms such as work placements and internships; programmes where students are partly located in the workplace, partly in the full-time study, such as apprenticeships, Sandwich courses or US Co-ops and programmes where students work full time and study part time. It includes academic staff members from universities and other higher education providers, administrators, policy makers and representatives from organisations engaged in this area of work. Members use the Network to publicise events, find partners and notify one another of vacancies and other opportunities. The membership continually expands so that now it is about 400 persons of whom three-quarters are UK-based members.

In the longer term, we would like the Network to give the sector a voice it so badly lacks at present. By its very nature, the sector is fragmented. "Work-based learning" in the UK for example, is not regarded as a "subject" by the Higher Education Statistics Agency so all the work that is undertaken under that heading is unrecorded. The result is a disjuncture between the knowledge and experience of those on the ground and policymakers. This has important consequences beyond mere party politics. There is a widespread crisis in productivity in many nations since the crash in 2008; whatever the solutions might be it is hard to believe that appropriate investment in genuine workplace learning is not at least part of the answer.

Every year the Network holds a one day conference which in 2020 will be at the University of Chester (cost $£ 60$ : UALL members £50). The main aim is to enable practitioners to share experience of practical pedagogic issues. The continuing growth of WBL in all its forms

(C) Jon Talbot and Paula McIver Nottingham. Published in Journal of Work-Applied Management. Published by Emerald Publishing Limited. This article is published under the Creative Commons Attribution (CC BY 4.0) licence. Anyone may reproduce, distribute, translate and create derivative works of this article (for both commercial and non-commercial purposes), subject to full attribution to the original publication and authors. The full terms of this licence may be seen at http://creativecommons. org/licences/by/4.0/legalcode

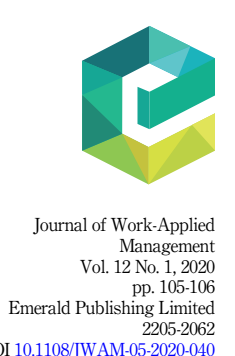

DOI 10.1108/JWAM-05-2020-040 
JWAM

12,1

106 presents particular challenges, especially for those more familiar with traditional delivery. Workshops will cover topics such as incorporating experiential learning into a formal academic curriculum, methods for accrediting past learning, delivery with external partners, quality assurance for non-standard programmes, managing student placements, creating practice knowledge for application within a formal academic framework, the role of workplace mentors, digital learning to support flexible delivery and administrative challenges for non-standard programmes.

If you would like more information on the Network and/or the conference please contact either Jon Talbot (j.talbot@chester.ac.uk) or Paula Nottingham (p.nottingham@mdx.ac.uk).

Jon Talbot and Paula McIver Nottingham

\section{Notes}

1. https://www.uall.ac.uk/

2. https://www.uallworkandlearning.org

\section{Reference}

HM Government (1919), Ministry of Reconstruction Adult Education Committee: Final Report, Cmd 321, HMSO, London. 